\title{
Time-varying correlation between oil and stock market volatilities: Evidence from oil-importing and oil-exporting countries
}

\author{
Rustam Boldanov $^{1}$, Stavros Degiannakis ${ }^{2,3}$, George Filis ${ }^{1, *}$ \\ ${ }^{1}$ Bournemouth University, Department of Accounting, Finance and Economics, Executive \\ Business Centre, 89 Holdenhurst Road, BH8 8EB Bournemouth. \\ ${ }^{2}$ Department of Economics and Regional Development, Panteion University of Social and \\ Political Sciences, 136 Syggrou Avenue, 17671, Greece. \\ ${ }^{3}$ Postgraduate Department of Business Administration, Hellenic Open University, \\ Aristotelous 18, 26 335, Greece.
}

*Corresponding author: email: gfilis@bournemouth.ac.uk

\begin{abstract}
This paper investigates the time-varying conditional correlation between oil price and stock market volatility for six major oil-importing and oil-exporting countries. The period of the study runs from January 2000 until December 2014 and a Diag-BEKK model is employed. Our findings report the following regularities. (i) The correlation between the oil and stock market volatilities changes over time fluctuating at both positive and negative values. (ii). Heterogeneous patterns in the time-varying correlations are evident between the oil-importing and oil-exporting countries. (iii) Correlations are responsive to major economic and geopolitical events, such as the early-2000 recession, the 9/11 terrorist attacks and the global financial crisis of 2007-2009. These findings are important for risk management practices, derivative pricing and portfolio rebalancing.
\end{abstract}

Keywords: conditional volatility, realized volatility, time-varying correlation, Diag-BEKK, GARCH, oil-importing countries, oil-exporting countries.

JEL: C32, C51, G15, Q40. 


\section{Introduction}

Over the last two decades a greater interest has been born to understand the impact of oil prices on the stock market. Some notable and influential studies have identified that there is a negative relationship between the two markets (see, inter alia, Jones and Kaul, 1996; Nandha and Faff, 2008; Miller and Ratti, 2009 and Chen, 2009). On the other hand, researchers argue that a positive relationship pertains to oil-exporting countries, while the adverse interaction only applies to oil-importing countries (see, indicatively, Bashar, 2006; Mohanty et al., 2011 and Wang et al., 2013).

Furthermore, many financial institutions and investors consider the oil market as a profitable alternative destination since it has low correlation with traditional asset classes and positive co-movement with inflation (see, for example, Kat and Oomen, 2007, and Silvennoinen and Thorp, 2010). Some authors put a question mark over these views suggesting that the oil market and the stock market could become highly linked due to the recent financialisation of the oil market, which is a result of the increased participation and speculation of hedge funds in the oil market (Byuksahin et al., 2010; Silvennoinen and Thorp, 2010; Tang and Xiong, 2010; Buyuksahin and Robe, 2011; Hamilton and Wu, 2012 and Sadorsky, 2014).

Overall, despite the increased interest in the stock-oil relationship, the literature has remained relatively silent about the relationship between the stock and oil market volatilities. It is since the late $80 \mathrm{~s}$ that Ross (1989) showed that asset price volatility holds important information and thus, volatilities from different markets could affect each other. More recently, Bloom (2009) and Baum et al. (2010) maintain that uncertainty in the oil market generates investment decision delays and, thus, increases stock market volatility. Linking all these studies together, we maintain that stock and oil market volatilities could exercise significant effects to each other.

Even more, the majority of the existing studies investigate the stock-oil relationship in a static environment. However, recent papers provide indisputable evidence that these markets do present dynamic interrelations (see, Bharn and Nikolovann, 2010; Choi and Hammoudeh, 2010; Filis et al., 2011; Filis et al., 2013; Antonakakis and Filis, 2013 and Filis, 2014, among others). Therefore, the relationship between stock and oil market volatilities could also present heterogeneous behaviour at different time period and thus it should be investigated with a dynamic approach. Thus, the aim of the present study is to investigate the time-varying 
relationship between stock and oil market volatilities in both oil-importing and oil-exporting countries.

More specifically, the objectives of the present paper are the following: i) to investigate the time-varying conditional correlation between stock and oil market volatilities, ii) to assess if this dynamic correlation is different for oil-importing and oil-exporting countries and iii) to examine changes in the dynamic correlation during major economic and geopolitical events.

To do so we focus on the stock markets of three oil-importing countries (S\&P500 index for the US, SSE composite index for China, and Nikkei 225 index for Japan) and oilexporting countries (OSEAX for Norway, S\&P/TSX for Canada and RTS for Russia), employing a Diag-BEKK model. The period of investigation runs from January 2000 until December 2014. Furthermore, oil and stock markets have showed severe boom and busts periods since 2000 .

The findings suggest that the correlation between the oil and stock market is indeed time-varying and it assumes both positive and negative values, although the positive values prevail. Furthermore, we notice that there is heterogeneous behaviour between the oilimporting and oil-exporting countries, as for the former group correlations are mainly positive, whereas this is not the case for the latter group. Finally, we show correlations are responsive to major economic and geopolitical events, such as the early-2000 recession, the 9/11 terrorist attacks and the global financial crisis of 2007-2009s.

The results have important implication for risk managers and investors as the correlation of these two asset classes could inform derivative pricing, portfolio rebalancing, as well as, risk management practices.

The rest of the paper is organised as follows. Section 2 provides the review of the literature, whereas Section 3 describes the data used in the study and Section 4 details the methods used. Section 5 analyses the findings and Section 6 concludes the study.

\section{Literature Review}

Many researchers claim that the impact of oil price fluctuation on stock returns is indirect and it is transmitted through macroeconomic variables. More specifically, oil is an important production input. Subsequently, any oil price escalation increases production costs, which, in turn, leads to higher prices and thus lower demand and consumer spending (Hamilton 1996, Huang et al., 1996, Arouri and Nguyen, 2010). Lower consumption results in a decreased production and eventually decreases employment (Lardic and Mignon, 2006; 
Davis and Haltiwanger, 2001). Accordingly, corporate earnings and dividends, which are key drivers of equity prices, decrease as well (Sadorsky, 1999; Al-Fayoumi, 2009).

A major body of empirical literature confirms these adverse effects of oil price changes on stock markets (Jones and Kaul, 1996; Ciner, 2001 and 2013; Papapetrou, 2001; Driesprong et al., 2008; Chen, 2009; Miller and Ratti, 2009). However, some researchers endorse the notion that this fact is relevant only for the oil-importing countries; whereas positive impacts of oil price movements on stock markets holds for the oil-exporting countries (Sadorsky, 2001; El-Sharif et al., 2005; Bashar, 2006; Boyer and Filton, 2007; O’Neill et al., 2008; Mohanty et al., 2011; Mohanty and Nandha, 2011; Arouri and Rault, 2012; Filis and Chatziantoniou, 2013; Wang et al., 2013).

On the other hand, some authors provide empirical evidence that oil price changes have little or no effects on stock market returns (Lescaroux and Mignon, 2008; Cong et al., 2008; Apergis and Miller, 2009; Al-Fayoumi, 2009 and Al Janabi et al., 2010). A plausible explanation of these little or no effects can be found on the fact that economies are able now to battle the economic consequences of oil price changes and thus these effects are not transmitted to the stock market. For example, Filis et al. (2011) state that currently monetary authorities put emphasis on their inflation stability and thus they prevent any inflationary pressures caused by oil price changes. Hence, they minimize the effects of oil price changes in the economy and thus in the stock market. Moreover, the International Energy Agency (2006), as well as Nordhaus (2007) and Blanchard and Gali (2007) suggest that the recent developments on investment, production, wage policies and renewable resources tend to minimise the consequences of oil price changes on the economies, as a whole and on stock markets, in particular.

However, we should not lose sight of the fact that oil price changes could exercise different effects on stock markets, depending on the nature of the oil changes. Hamilton (2009a, 2009b) shows that oil price changes can be triggered by demand- and supply-side events. He explains that demand-side oil price shocks are triggered by changes in the global aggregate demand (e.g. due to China's industrialisation, global recessions), whereas supplyside oil price shocks are generated due to change in global oil supply (e.g. due to OPEC decisions to cut or increase oil production or due to disruptions in the oil supply due to severe weather conditions). Evidence suggests that demand-side shocks exercise positive impacts to economic activity compared to the negative effects of supply side shocks. Additionally, Kilian (2009) identified a third oil price shock by disentangling the demand-side shock into aggregate demand shocks (which is the same as Hamilton's demand-side shock) and the 
precautionary oil demand shock, which reflects the uncertainty about the future availability of oil. The later shock is triggered by events such as war conflicts in the Middle East or terrorist attacks. Overall, it is evident that all three oil prices shocks are directly related to major economic and geopolitical events.

Kilian and Park (2009) shows that stock markets respond positively to aggregate demand shocks, whereas a negative response in observed in the case of precautionary demand shocks. Additional empirical evidence suggests that a positive correlation exists between positive aggregate demand shocks and financial or economic returns, whereas the reverse is true for positive precautionary demand and supply-side shocks (Lescaroux and Mignon, 2008; Kilian and Park, 2009; Apergis and Miller, 2009; Filis et al., 2011; Basher et al., 2012; Baumeister and Peersman, 2012; Chen et al., 2014). Furthermore, many researchers consolidate the concept that supply-side shocks do not exercise any effect on economic activity or financial markets (Barsky and Kilian, 2004; Kilian, 2008; Hamilton, 2009; Filis et al., 2011; Sadorsky et al., 2012; and Degiannakis et al., 2014).

These past studies focus on stock market returns and oil price returns (or shocks). Nevertheless, the interaction between the oil market and the stock market may potentially occur through their volatilities (Huang et al., 1996). An early study on the effects of oil price volatility on the stock market is this by Sadorsky (1999). His findings reveal that oil price volatility tends to have asymmetric effects on the US stock market returns, showing that the impact of the positive shocks in the oil price volatility exerts a significantly greater impact on US stock returns, compared to the negative shocks. More recently, Park and Ratti (2008) also suggest that oil price volatility contributes negatively to changes in stock returns in the US and in thirteen European countries. However, this finding does not hold true for the Norwegian stock market, which seems to respond positively to increases in oil price volatility, possibly due to the fact that Norway is a major oil exporter. Ratti et al. (2011) seconds these findings. Furthermore, oil price shocks, and more specifically the aggregate demand shocks also impact stock market volatility, as Degiannakis et al. (2014) show.

Despite the few studies that concentrate on oil market or stock market volatility, there is no evidence on the relationship between the volatilities of the two markets. This study aims to fill this void. Even more, we examine the aforementioned relationship in a time-varying environment. This choice is justified by the fact that an emerging strand in the literature has shown that the relationship between the oil and stock market returns is indeed dynamic (see, Aloui and Jammazi, 2009; Choi and Hammoudeh, 2010; Bharn and Nikolovann, 2010; Filis 
et al., 2011; Broadstock et al., 2012; Sadorsky, 2012; Broadstock and Filis, 2013; Chang et al., 2013; Antonakakis and Filis, 2013; Filis, 2014).

Indicatively, Choi and Hammoudeh (2010) employ a DCC model to examine the correlation between the stock market and oil markets (among other commodities) since Iraq war in 2003 and report that this correlation is decreasing over time and negative. Similarly, Bharn and Nikolovann (2010) focus on the Russian stock market and the evidence suggests that there is a permanent negative correlation between oil price changes and stock market returns over the period of 1995-2007. More recently, Broadstock et al. (2012) employ a BEKK model to examine the time-varying correlation between oil price changes and energyrelated equities in China. They find that the correlation increases significantly since the peak of the global financial crisis of 2007-2009. Along a similar vein, Broadstock and Filis (2013) extend this strand of the literature focusing on the dynamic relationship between each of the three oil price shocks, which are identified by Kilian (2009) and the stock market returns of the US and China. Using a Scalar-BEKK model they find that the US stock market seems to have greater correlation over time with oil price shocks compared to Chinese stock market returns. Furthermore, they show that the correlation fluctuates in both the positive and the negative regions, depending on the period. Finally, Filis (2014) also uses a Scalar-BEKK model to examine the dynamic co-movements between stock market returns and oil price shocks for six oil-importing and two oil-exporting countries. The findings of the study second those by Broadstock and Filis (2013).

Overall, this study extends the literature in the oil-stock relationship focusing on the time-varying correlation between the volatilities of the two markets for both oil-importing and oil-exporting countries. Thus, we posit the following hypotheses:

Hypothesis 1: The relationship between the volatilities of the oil and stock markets is timevarying.

Hypothesis 2: There is a difference in the time-varying volatility correlations in oilimporting and oil-exporting countries.

Finally, given that the literature has shown that the relationship between oil and stock market could exhibit a heterogeneous pattern during economic and geopolitical events, we posit a third hypothesis, as follows:

Hypothesis 3: There is a heterogeneous behaviour of the time-varying volatility correlations during period of economic and geopolitical uncertainty. 


\section{Data Description}

We use daily closing prices for the Brent crude oil price and six stock market indices over the period from January 2000 through to December 2014, in order to construct their monthly volatilities. The six market indices represent three oil-exporting countries (TSX (Canada), RTS (Russia), OSEAX (Norway)) and three oil-importing countries (S\&P 500 (the US), SSE (China) and Nikkei 225 (Japan)). The Brent crude oil price is used for analysis as the prices generated in the Brent basket compose the main price benchmarks on the basis of which 70 percent of international trade in oil is directly or indirectly priced (Fattouh, 2011). All variables are expressed in US dollar terms.

The data for the Brent oil price have been obtained from the Energy Information Administration, whereas the data for stock markets has been retrieved from DataStream ${ }^{\circledR}$. The daily oil price and stock index returns were generated as the first log-difference, $y_{t}=$ $\log \left(\frac{P_{t}}{P_{t-1}}\right)$, where $P_{t}$ reflects the daily closing price at the given time $\mathrm{t}$.

The choice of countries in our sample is motivated by the fact that they are all among the largest oil importers and oil exporters. Section 3.1 and 3.2 provides some details for the oil sectors of the chosen countries.

\subsection{Oil-importing countries}

The three oil-importing countries in our sample are Japan, China and the US. According to data provided by OPEC (2014), China's net oil imports were 5.7 million barrel per day in 2013, while the US imported 7.7 million barrel per day, being the world's second and first largest oil importers respectively. Nevertheless, an EIA's report (2013) claims that it is expected that China's net oil imports would surpass the net oil imports of the US on annual bases by the end of 2014. To a large extent this is due to the US have increased its own production, while China has been involved in oil consumption growth despite the fact that slower economic activity is observed.

Japan is the third largest oil consuming and importing country. The country's net imports of crude oil not counting domestic oil production remained 4.4 million barrels per day in 2014. Nonetheless, Japan experienced a dramatic increase in oil imports after the Fukushima incident and earthquakes in the middle of 2011. The loss of nuclear power generating plants led to use crude oil for direct burning in electricity plants (EIA, 2015). On the other hand, the Japanese government maintains control of oil stocks to guarantee stable crude oil imports in the event of supply disruption. For example, Japan signed contracts with oil-exporting 
countries to lease oil storage for 12.6 million barrels in 2015, and uses strategic oil storage in Japan for 420 million barrels (International Energy Agency, 2014).

In the current research, the Japanese, Chinese and the US stock market indices are represented by the Nikkei 225, Shanghai Composite and the S\&P 500, respectively. Interestingly enough since the earthquakes and the difficulties of the economic activity in Japan, its stock market moved from the world's best performing stock market to the most volatile one (Harlan, 2013).

\subsection{Oil-exporting countries}

Regarding oil-exporting countries, Norway is the largest oil exporter in Europe. The country exported 1.28 million barrels of oil per day in 2014, where around $98 \%$ of exports went to European countries. For the Norwegian stock market we use the OSEAX index, which represents all equities listed at the Oslo Stock Exchange (EIA, 2015).

Canada exported 3.32 million barrels of oil per day in 2014, ranking the country among the world's top ten largest oil-exporters, where approximately $99 \%$ of exports were to the US (National Energy Board, 2015). The research uses the S\&P/TSX composite index that represents the largest companies listed on Toronto Stock Exchange.

The 5 million oil barrels per day that the Russian Federation exports to the world account for the $33 \%$ of Russia's total export revenue. The country ranks third among the world's top net oil-exports after Saudi Arabia and the US (EIA, 2014). According to Bhar and Nikolova (2010), Russia's economic growth is mostly driven by its energy sector and in particular its revenue from oil and gas sales. The stock market index that we focus on in the study is the RTS index, which contains the fifty largest companies listed on the Moscow Exchange (the majority of equities in the index pertain to oil and gas industry).

\section{Model Framework}

We investigate the relationship between the volatility of oil price and stock market returns. Nonetheless, it is first required to estimate the respective volatilities.

\subsection{Estimation of volatility}

\subsubsection{Conditional volatility}

Oil and stock market volatilities are presented as conditional volatilities, which can be defined as a conditional standard deviation of returns based the most recent available 
information. For example, the stochastic process for log-returns, $y_{t}$, can be described by conditional movement given the information set $I_{t-1}$ denoted as $V\left(y_{t} \backslash I_{t-1}\right) \equiv \sigma_{t}^{2}$. In this context, $\sigma_{t}^{2}$ is represented with the volatility of returns at the time $t-1$.

We implement the standard GARCH model proposed by Bollerslev (1986) to generate conditional volatility of daily log-returns. However, despite the fact that the GARCH model has its own drawbacks, it provides the simple but successful way to capture volatility clustering (see Hansen and Lunde, 2005) ${ }^{1}$. The univariate $\operatorname{GARCH}(p, q)$ model is estimated under assumption of a Student $t$ distribution:

$$
\begin{gathered}
y_{t}=c_{0}+\varepsilon_{t} \\
\varepsilon_{t}=\sigma_{t} z_{t} \\
\sigma_{t}^{2}=\alpha_{0}+\sum_{i=1}^{q} \alpha_{i} \varepsilon_{t-i}^{2}+\sum_{j=1}^{p} \beta_{j} \sigma_{t-j}^{2} \\
f(t)=\frac{z_{t} \sim t(0,1 ; v)}{\sqrt{\pi} \Gamma\left(\frac{v}{2}\right) \sqrt{\left.\frac{v+1}{2}\right)}}\left(v+\frac{v t^{2}}{(v-2) \sigma_{t}^{2}}\right)^{-(v+1) / 2},
\end{gathered}
$$

where $\varepsilon_{t}$ is the demeaned return at time $t, \sigma_{t}^{2}$ is the conditional variance at time $t, z_{t}$ represents the sequence of identically distributed standardized residuals and $t(0,1 ; v)$ is the Student $t$ density function, $\alpha_{0}, \alpha_{i}, \ldots, \beta_{j}$ are parameters of the model and $i, j$ are the lag orders. The parameters $\alpha_{0}, \alpha_{i}$ and $\beta_{j}$ are non-negative, where $\alpha_{0}>0, \alpha_{i}, \beta_{j} \geq 0$, whereas $v>2$ is the degrees of freedom. The reason of using Student $t$ distribution is that GARCH models often have an issue in capturing the thick tails property of financial time series and it is recommended to apply non-normal distributions to better model this excess kurtosis (Bollerslev, 1987; Kaiser, 1996; Beine et al., 2000, and Peters, 2001) ${ }^{2}$.

The current research focuses on monthly conditional volatility, which is calculated by summing the daily conditional variance. Merton (1980) has introduced the concept of applying high frequency data to capture the volatility at lower frequency. Furthermore, empirical evidence suggests that GARCH models with high frequency data provide accurate

\footnotetext{
${ }^{1}$ We have also considered an asymmetric power ARCH (APARCH) model for the estimation of conditional volatility, as in Degiannakis et al. (2014). The results of the time-varying correlations based on the APARCH conditional volatilities are qualitatively similar and available upon request.

${ }^{2}$ We have tested for auto-correlation, heteroscedasticity and the adequacy of the Student $t$ distribution and the test statistics confirm the validity of our model specification. The lag orders $p, q$ were selected according to the SBC criterion of Schwarz (1978). We have also tested for ARCH effects on the monthly volatility series and the results are highly statistically significant.
} 
volatility estimation (Andersen and Bollerslev, 1997 and 1998). Consequently, the annualized monthly conditional volatility $\left(C V_{t}^{(m)}\right)$ is calculated as the square root of the sum conditional variances:

$$
C V_{t}^{(m)}=100 \sqrt{12 \sum_{t=1}^{\tau} \sigma_{t}^{2}},
$$

where $\sigma_{t}^{2}$ is the daily conditional variance and $\tau=22$ is the number of trading days of a month.

\subsubsection{Realized volatility}

We also consider the realized volatility measures for both oil and stock returns. The construction of realized volatility measures is based on the idea that higher frequency data can be used to compute volatilities at lower frequencies (Merton, 1980).

For this study we measure the monthly realized volatility, dividing the monthly time period in equidistance trading days $(j)$. Thus, the annualized realized volatility of month $t$, or $R V_{t}^{(m)}$, is computed as follows:

$$
R V_{t}^{(m)}=100 \sqrt{12 \sum_{j=1}^{\tau}\left(\log P_{t_{j}}-\log P_{t_{j-1}}\right)^{2}}
$$

where $\log P_{t_{j}}$ is the natural logarithm of the daily oil or stock market prices at trading day $j$. Given that realized volatility will be higher in the months that have more trading days (even if the volatility does not change), we scale $R V_{t}^{(m)}$ with $\sqrt{22 / \tau}$.

\subsection{Estimation of conditional correlation between volatilities}

The aim of this study is to investigate the time-varying correlation between the volatilities of oil and stock market returns. Thus, there is no intention either to disentangle the oil price shocks or to examine exogenous variables that could have an impact on the volatilities of the two markets.

In this study we employ a BEKK-family model (Baba et al., 1991; Engle and Kroner, 1995 ) for the estimation of the time-varying correlation ${ }^{3}$. According to Broadstock and Filis

\footnotetext{
${ }^{3}$ The use of GARCH models on monthly series accords with the literature (see, for instance, Broadstock and Filis, 2014; Filis, 2014; Antonakakis et al., 2013)
} 
(2013) and Filis (2014) in their studies stated that the BEKK model may be superior to DCC and, thus, it is preferred. More specifically, they base their argument on two papers by Caporin and McAleer $(2008,2012)$ who reveal that DCC does not deliver an accurate dynamic correlation, as opposed to the BEKK model that it does. Furthermore, the current study uses a Diag-BEKK, given that the low sample size requires a more parsimonious model. The estimation parameters of the Diag-BEKK are $(n(l+k))+3$, where $n$ is the dimension of the model; i.e. the number of dependent variables and $l$ and $k$ are the lag orders. The Diag-BEKK model provides assurance of positive definiteness of the conditional covariance (correlation) matrix with few parameters of estimation ${ }^{4}$.

Following with the previous section of GARCH model application, the time-varying correlation framework conducts a bivariate Diag-BEKK specification under the Student $t$ distribution ${ }^{5}$ :

$$
\boldsymbol{S}_{t}-\left[\begin{array}{c}
C_{0, \text { stock }} \\
c_{0, o i l}
\end{array}\right] \mid I_{t-1} \sim t\left(\mathbf{0}, \boldsymbol{H}_{t}\right),
$$

where, $\boldsymbol{c}_{0} \equiv\left[\begin{array}{ll}c_{0, \text { stock }} & c_{0, \text { oil }}\end{array}\right]^{\prime}$ is the mean value, $I_{t-1}$ is the information set at a given time and the bivariate vector $\boldsymbol{S}_{t}=\left[\begin{array}{c}C V_{t, s t o c k}^{(m)} \\ C V_{t, \text { oil }}^{(m)}\end{array}\right]$ denotes the stock return volatility and the volatility in oil price returns ${ }^{6}$. The variance-covariance matrix of the $\operatorname{Diag-\operatorname {BEKK}}(l, k)$ is defined as follows:

$$
\boldsymbol{H}_{t}=\boldsymbol{A}_{0}+\sum_{i=1}^{k}\left(\boldsymbol{A}_{i} \boldsymbol{\varepsilon}_{t-i} \boldsymbol{\varepsilon}_{t-i}^{\prime} \boldsymbol{A}_{i}^{\prime}\right)+\sum_{j=1}^{l}\left(\boldsymbol{B}_{j} \boldsymbol{H}_{t-j} \boldsymbol{B}_{i}^{\prime}\right)
$$

In this context, $\boldsymbol{A}_{0}=\left[\begin{array}{ll}a_{1,1,0} & a_{1,2,0} \\ a_{1,2,0} & a_{2,2,0}\end{array}\right]$ is a $(2 \times 2)$ matrix and the $\boldsymbol{A}_{i}$ and $\boldsymbol{B}_{j}$ matrices are restricted to be diagonal. Based on this model, the conditional covariance matrix for two variables is $\boldsymbol{H}_{t}=\left[\begin{array}{ll}h_{1,1, t} & h_{1,2, t} \\ h_{2,1, t} & h_{2,2, t}\end{array}\right]$ and the dynamic conditional correlation between oil price

\footnotetext{
${ }^{4}$ For robustness purposes we have also used a Scalar-BEKK with Student $t$ distribution and the results are qualitatively similar. The results are available upon request.

${ }^{5}$ We intentionally exclude lags of the endogenous variables in the mean equation, as we are interested on the time-varying correlation of the oil and stock volatilities, rather than the unexplained component of their volatilities, once the autocorrelation has been removed. We take this stance as it is more appropriate for the investors. For instance, let us assume a two-asset portfolio with auto correlated assets and an investor that is interested to identify the time-varying optimal hedge ratio. Let us also assume that the correlation of the two assets is zero, once the autocorrelation has been removed. This result will be of no use to the investor if in the real world, the two assets had some sort of correlation, even if this was due to their autocorrelation. For additional justification of using this mean equation, please see Degiannakis et al. (2013).

${ }^{6}$ This paper does not investigate the role of other variables (exogenous or not) in influencing the time-varying correlations between oil and stock market volatilities. The inclusion of such additional variables would create issues related to footnote 5 of this paper.
} 
returns volatility and volatility in stock returns can be estimated by $\rho_{t}=\frac{h_{1,2, t}}{\sqrt{h_{1,1, t}} \sqrt{h_{2,2, t}}} .{ }^{7}$ The models are estimated using the maximum likelihood approach. The likelihood function is estimated with the constraint optimization MaxSQPF algorithm. MaxSQPF implements a sequential quadratic programming solution, for linear and non-linear restrictions ${ }^{8}$. The specifications of Diag-BEKK parameters and equations have been obtained from Xekalaki and Degiannakis $(2010)^{9}$.

\section{Findings and Analysis}

\subsection{Preliminary analysis and descriptive statistics}

Figure 1 exhibits the evolution of the conditional and realized volatility series for all our variables.

\section{[FIGURE 1 HERE]}

There is a distinct episode that emerges from Figure 1 and this is related to the effects of the global financial crisis of 2007-2009, where volatility series have reached unprecedented levels. Furthermore, another peak can be observed during 2001 period for all volatility series, apart from the three oil-exporting countries, which can be related to the early-2000 recession of the US and the 9/11 terrorist attack.

Specifically, for the oil price volatility we observe two more important spikes in the early 2003 and between 2004 and 2005, respectively. These spikes are associated with the second war in Iraq in 2003 and the period of the highest activity of Atlantic hurricanes in 2004-2005. More specifically, Hurricane Katrina severely damaged ten refineries in the Gulf of Mexico, which resulted in major supply disruptions. Interestingly enough, we do not observe an escalation of the oil volatility during the period 2011-2014 (apart from the later part of 2014) when a number of geopolitical events occurred, such as the Arab spring and the Libyan and Syrian civil wars.

\footnotetext{
7 The aim of the study is to solely examine the time-varying correlations between oil and stock market volatilities and we do not focus on their spillover effects. If we were interested on spillover effects, then it would be more appropriate to use models such as a VARMA-GARCH.

${ }^{8}$ Technical information is available in Doornik (2007) and Lawrence and Tits (2001). MaxSQPF is useful to impose the stationarity an positivity constraints. Without imposing any restrictions it delivers the BFGS algorithm. The BFGS method was developed by Broyden (1970), Fletcher (1970), Goldfarb (1970), Shanno (1970). The covariance matrix is estimated according to the Quasi Maximum Likelihood or Sandwich formula method.

${ }^{9}$ We have tested for the adequacy of the Student $t$ distribution and the results confirm the validity of the proposed model specification. The lag orders $k, l$ were selected according to the SBC criterion.
} 
Turning to the volatilities of the stock markets, Figure 1 shows that stock market volatility for oil-exporting countries are more volatile compared to oil-importing countries. Furthermore, we notice that the volatilities of oil-exporting stock markets appear to have more homogeneous patterns compared to those of the oil-importing countries. A distinct observation is the increase in the volatility of the Russian index during 2014, which is related to the instability in Ukraine. Concerning the oil-importing countries, it is important to note that the Chinese stock market did not show a significant increase in its volatility during the global financial crisis compared to the other markets, possibly due to the fact that the Chinese economy was significantly more resilient to the crisis compared to the other countries in our sample. Given that conditional and realized volatility series exhibit similar patterns, from this point onwards we report only the findings from the conditional volatility.

Table 1 shows the descriptive statistics of the conditional volatility series. From Table 1 we notice that the highest average volatility can be observed in Russian stock market (RTS) followed by the oil price volatility, while the lowest average is in the US stock index (S\&P500). This is somewhat expected given the fact that the Russian stock market is still an emerging market, whereas the US is the largest mature market in the world. Concerning standard deviation, it seems that oil-exporting countries exhibit a more volatile behaviour in their volatilities compared to oil-importing countries. Similar observations were made in Figure 1, as well.

\section{[TABLE 1 HERE]}

In terms of distributions, estimated conditional volatility for oil price and stock markets are positively skewed, representing that positive values are more likely and there is movement from symmetry by a longer tail on the right side of the probability density function. Regarding kurtosis, all variables demonstrate a leptokurtic distribution, as kurtosis is much higher than 3 and indicates a larger possibility of extreme movements in the time series. Moreover, the Jarque-Bera test rejects the null hypothesis of normal distribution at the $1 \%$ significance level for all volatilities. Finally, the ADF test shows that all volatility series are stationary. All assumptions tested for conditional volatility show the adequacy of applying the Diag-BEKK model.

Finalising this preliminary analysis, it would be interesting to examine the unconditional correlation between the oil and stock market volatilities (see Table 2).

\section{[TABLE 2 HERE]}

According to Table 2, all unconditional correlations are positive, as expected. However, it can be noted that oil prices volatility is more correlated with oil-exporting 
countries rather than oil-importing countries. Namely, the Canadian (TSX) and Russian (RTS) stock volatilities have the highest positive correlation with oil price volatility, 0.604 and 0.586, respectively. On the other hand, the Chinese stock market (SSE) volatility has the lowest correlation with the oil price volatility (0.033). A plausible explanation of the later observation can be found in Broadstock and Filis (2014) where they show that the Chinese stock market is resilient in the fluctuations of the oil prices. Nevertheless, given that a number of events (either economic or geopolitical) took place during the year 2000-2014, as noted in Figure 1, it should not be expected that the correlations of Table 2 would hold for the whole period. Thus, we proceed with the examination of the dynamic conditional correlation, which will shed more light on the actual relationship of these volatilities.

\subsection{Empirical results on dynamic conditional correlation}

Table 3 reports the estimates of time-varying correlations of stock market and oil price conditional volatility, using the Diag-BEKK model. The Ljung-Box test implemented using order up to 15 lags. The results of diagonal tests show that standardized residuals and squared standardized residuals show the significance of bivariate Diag-BEKK model to capture the time-varying conditional correlation between volatilities in oil price and stock market.

Regarding the estimations of the mean and variance equations of the Diag-BEKK model, it has been found that coefficients are highly significant for all six stock market indexes.

\section{[TABLE 3 HERE]}

Figures 2 and 3 present the time-varying correlations for oil-importing and oilexporting countries, respectively ${ }^{10}$. The time-varying correlations indicate that, whether it is an oil-exporting country or oil-importing country, the dynamic correlation between oil and stock market conditional volatilities fluctuate in both the positive and negative region, although in most cases positive correlations prevail. This is suggestive of the fact that the positive unconditional correlations which were observed in Table 1 are not adequate the reveal the true relationship among the series. Furthermore, a preliminary look at Figures 2 and 3 suggests that there are no significant differences between the correlations of the oilimporting and oil-exporting countries. Nevertheless, it is appropriate to examine the time-

\footnotetext{
${ }^{10}$ The time-varying correlations based on the realized volatility measures are available in the Appendix.
} 
varying conditional correlation for each country by analysing its behaviour during major economic and geopolitical events.

[FIGURE 2 HERE]

[FIGURE 3 HERE]

\subsubsection{The case of the oil-importing countries}

Figure 2 demonstrates time-varying correlations between oil and stock market volatilities for oil-importing countries.

It can be observed that the time-varying correlations do not differ significantly, especially those of the S\&P500 and the NIKKEI225 indices. Starting with the 2000-2001 period, which is related to the dot-com bubble, the early-2000 recession in the US and the 9/11 terrorist attack, we notice that for the US and Japan, the correlations are strong positive. By contrast, the Chinese stock market volatility mainly exhibits a negative correlation during this period. A plausible explanation for this correlation is the fact that during the period 20002001 the Chinese stock market was booming and thus experiencing low levels of volatility, contrary to the US and Japan. The strong positive correlation that we observe at the end of 2001 is related to the September 2001 terrorist attack in the US, which had a significant negative impact on all stock markets, as well as, the oil market.

Continuing along the time-line of major events, it can be indicated that during the second US invasion in Iraq in 2003 the US market volatility has a moderately strong correlation with oil price volatility, whereas the Chinese and Japanese stock market volatilities exhibited correlations close to zero. This could be justified by the fact that the war in Iraq in 2003 impacted mainly the US stock market rather than the two Asian markets.

The next major event that significantly impacted oil prices was during 2004-2005, which was the year with the highest activity of Atlantic hurricanes. The time-varying correlations are fluctuations in the negative region for all oil-importing countries, although the magnitude differs. This is suggesting of the fact that despite the uncertainty that the hurricanes created in the oil market, stock markets remained relatively calm.

Some interesting patterns can be observed during the period 2006-2007. This is period when the rapid economic growth of emerging countries, particularly of China, led oil prices in unprecedented levels. The time-varying correlation at the period is highly positive for both the US and Japan, yet a moderate negative correlation is recorded in the case of China. This is a rather interesting finding, given that during 2006-2007 oil volatility is very low and one would expect the same for the Chinese volatility, given the incredible growth that the Chinese economy was experiencing then. On the contrary the period 2006-2007 is very volatile for the 
SSE index mainly due to the valuation methodology of Chinese stock market, which was integrated with international standards for the first time but also due to a split share structure reform and the sustainable growth of listed companies (Yao and Luo, 2009; Cheng and Li, 2014). The empirical findings by Broadstock et al. (2012) demonstrate substantially similar fluctuations in the correlation between oil price and stock market returns for this period.

Correlations for the oil-importing countries reach a peak during the global financial crisis of 2007-2009, which is expected given the uncertainty that the Great Recession caused not only in the stock markets but also in the oil market. Once again China is exhibiting a somewhat different magnitude as its correlation does not reaches the value of 1 during the peak of the financial crisis, as it is the case with Japan and the US. This is explained by the fact that the Chinese stock market volatility did not exhibited a huge increase during this period, as the Chinese economy on one hand slowed down but on the other hand it did not enter into recession.

The period of 2011-2014 is associated with continues unrest in the Middle East, which was initiated with the Arab Spring and continued with the civil wars in Libya and Syria, as well as, with turbulence in Egypt, Yemen and Bahrain, among other countries. During these three years the correlations are mainly positive for all markets, apart from the middle of 2013 when the correlations for China and Japan turn to a negative sign. This finding is rather interesting, as the positive correlations observed in Figure 2 are not due to synchronous increases in the volatilities of these markets, but on the contrary due to the simultaneous downward trend in their volatilities. This is somewhat unexpected given that Middle East conflicts have traditionally caused precautionary demand shocks in oil prices, which are uncertainty bearing shocks and thus volatilities (especially for the oil prices) would be expected to increase. Nevertheless, this could point out that markets (either oil or stock) are more sanguine about geopolitical risks.

At the end of our sample period we observed a spike in oil volatility (see Figure 1). This is due to the collapse of the oil prices during the second half of 2014. Oil price declined for two main reason. First, economic activity was weak, which resulted in a decrease in oil demand. More importantly, though, there was no reaction from OPEC to decrease. Even more, the crisis in Ukraine contributed further to the spike in oil price volatility. The timevarying correlation exhibit a declining pattern during the latter part of 2014, suggesting that these events are mainly oil specific and they did not impact the stock markets of the three oilimporting countries, in our sample. 
Overall, it is clear that the conditional correlation of the Chinese stock market has lower values compared to Japan and the US. Broadstock et al. (2012) and Nguyen and Bhatti (2012) also claim that the Chinese stock market index does not receive a significant impact oil prices, especially until the global financial crisis. A plausible explication could be found in the fact that China had a stable economic growth 2007 and thus the country was able to absorb the changes in oil prices. Furthermore, this finding can be explained by the fact that China's stock market was mainly driven by internal factors until the global financial crisis, whereas the continuous urbanisation and industrialisation of China leads its stock market to become significantly more influenced by international factors (Broadstock and Filis, 2014). This could also explain the fact that SSE volatility fluctuates more closely with the other two volatilities in the post-global financial crisis period.

\subsubsection{The case of the oil-exporting countries}

Turning to the time-varying conditional correlations between oil price volatility and stock market volatility for oil-exporting countries (see Figure 3) we notice that, contrary to the oil-importing countries, they tend to exhibit more negative correlations (especially the cases of Norway and Canada). This is a first indication that indeed the behaviour of the correlations is different for the oil-importing and the oil-exporting countries.

The period 2000-2001 is generally associated with positive correlations between oil price volatility and stock market volatility for all three oil-exporting countries. The strongest average correlation between volatilities is observed in the Canadian index, with 0.88 , and the Russian index, with 0.57 , while the Norwegian stock market volatility was correlated with oil price volatility at average of 0.23 in this period, mainly due to the fact that during the second half of 2000 its correlation with oil volatility is moderately negative. Focusing on the 9/11 terrorist attack, this resulted in strong positive correlations for all three countries, which was close to one.

The war in Iraq drives the time-varying correlations for all three countries towards moderate negative values, which is somewhat different to the oil-importing countries which showed either positive or zero correlations during the same period. The Canadian stock market's volatility's correlation with oil price volatility suffered most from this shock, indicating negative sign below 0.5 .

Furthermore, similar to the case of the oil-importing countries, the hurricane period of 2004-2005 results in negative correlations between oil and stock market volatilities in the oilexporting countries. During the following two periods of 2006-2007 (the economic growth of 
the emerging countries) and 2007-2009 (the global financial crisis), the time-varying correlations resemble those of the oil-importing countries. Nevertheless, in the late 2007 correlations are negative for Norway and Canada. According to Bhar and Nikolova (2010), the Russian stock returns and volatility are driven by high oil prices and a strong global oil demand, since the stock represents the majority equities that relate to the oil and gas industry. Consequently, it can be concluded that this could be the reason why the Russian stock market exhibits a constant positive correlation during these years.

The next period which is linked to a prolonged period of geopolitical unrest in the Middle East (2011-2014) reveals strong positive correlations for three oil-exporting countries for the largest part of the period, which are similar to these of the oil-importing countries, although the magnitude is higher. It is worth noting, though, that during the early part of this period correlations for Norway and Canada are moderately to strongly negative.

Finally, it is worth noting that the volatility correlations exhibited a decreasing pattern during the latter part of 2014 for all three countries, as in the case of the oil-importing countries.

\section{Discussion of the results and concluding remarks}

The current research sheds light on the dynamic conditional volatility correlation between the oil and stock markets by comparing the oil-importing and oil-exporting countries. Our sample period runs from January 2000 until December 2014 and a DiagBEKK is used for the estimation of the time-varying correlations. This study focuses on the conditional volatility, as this has been estimated by a $\operatorname{GARCH}(1,1)$ model.

Overall, our findings confirm our first hypothesis and complement the past empirical evidence, which focus on oil and stock market returns and suggests that the relationship between the oil and financial markets does not remain constant but rather it behaves heterogeneously over different time periods (Bharn and Nikolovann, 2010; Choi and Hammoudeh, 2010; Filis et al., 2011; Filis et al., 2013; Antonakakis and Filis, 2013 and Filis, 2014).

Table 4 exhibits the summary of findings for the time-varying correlations between oil price volatility and stock market volatility during different economic and geopolitical events. We further distinguish between the correlations of the oil-importing and oil-exporting countries.

[TABLE 4 HERE] 
It is evident that the dynamic correlations are nearly always positive for oil-importing countries. Although a moderate negative correlation is detected for the Chinese stock market volatility during the period 2006-2007. The period that correlation is negative for all oilimporting stock markets is the Atlantic hurricane period of 2004-2005.

Turning to the oil-exporting countries we find that there are three periods which results in negative correlations (i.e. during the US invasion in Iraq, the Atlantic hurricanes and the early years in the Middle East conflicts). Positive correlations are detected in all other cases for all three oil-exporting countries. Based on this finding we claim that we confirm the second hypothesis that the time-varying correlations are different depending whether a stock market belongs to an oil-importing or oil-exporting country.

Furthermore, a close investigation of these economic and geopolitical events allow us to understand that during periods that trigger either aggregate demand (e.g. the early-2000 recession, the Chinese economic growth or the global financial crisis of 2007-2009) or precautionary demand oil shocks (e.g. the 9/11 terrorist attack, the US invasion in Iraq or the Middle East conflicts), the correlations are positive for almost all markets. By contrasts during supply-side events (e.g. the Atlantic hurricane period) correlations become negative.

This finding is in line with the studies by Hamilton (2009), Kilian and Park (2009), Apergis and Miller (2009), Baumeister and Peersman (2012), Wang et al. (2013) and Kang et al. (2015), among others, which suggest that different oil shocks trigger different responses from the stock markets. Nevertheless, our results regarding the supply-side shocks cannot confirm the previous evidence, which suggests that these oil price shocks tend not to have any effect on financial markets (Filis et al., 2011; Sadorsky et al., 2012; and Degiannakis et al., 2014). This last finding allows us to confirm our third hypothesis, which suggests that correlations change during different economic and geopolitical events.

We should not lose sight of the fact, though, that in most cases the correlation is positive, although of different magnitude. Thus, the argument put forward by authors, such as Byuksahin et al. (2010), Silvennoinen and Thorp (2010), Tang and Xiong (2010), Byuksahin and Robe (2011), Hamilton and Wu (2012) and Sadorsky (2014), among others, that the speculation and the financialisation of the oil market resulted in an increased correlation between the oil market and the stock market, can be also confirmed in this paper. However, this holds primarily for the oil-importing countries, as these are the countries that mainly exhibit positive correlations between their volatilities and oil price volatility for almost the whole time period. 
Since volatility is considered as a key element of financial instruments, our findings are important for investors who are seeking to consider the oil market as part of their portfolio of investments. Furthermore, these results are important for derivative pricing, given that volatility is a key component. Finally, our findings should be considered when investors or financial managers make decisions related to risk management and portfolio rebalancing between the two markets.

For further research, it would be interesting to examine the dynamic volatility correlations between oil and industrial sectors. Finally, given the raising importance of other commodities in portfolio construction, further studies should focus on the time-varying correlations between volatilities of different asset classes and commodities.

\section{Acknowledgements}

The authors would like to thank Prof. Brian M Lucey (Editor) and the anonymous reviewer for their helpful comments on a previous version of this paper. We would also like to thank the participants of the $6^{\text {th }}$ National Conference of the Financial Engineering and Banking Society for their comments. George Filis and Stavros Degiannakis acknowledge the support of the European Union's Horizon 2020 research and innovation programme, which has funded them under the Marie Sklodowska-Curie grant agreement No 658494. All views expressed in this paper, and any remaining errors or omissions, remain the responsibility of the authors.

\section{References}

Al Janabi, M. A. M., Hatemi-J, A. and Irandoust, M. (2010). An Empirical Investigation of the Informational Efficiency of the GCC Equity Markets: Evidence from Bootstrap Simulation. International Review of Financial Analysis, 19(1), 47-54.

Al-Fayoumi, N.A. (2009). Oil Prices and Stock Market Returns in Oil Importing Countries: The Case of Turkey, Tunisia and Jordan. European Journal of Economics, Finance and Administrative Sciences, 16, 86-101.

Aloui, C. and Jammazi, R. (2009). The Effects of Crude Oil Shocks on Stock Market Shifts Behaviour: A Regime Switching Approach. Energy Economics, 31(5), 789-799.

Andersen, T.G. and Bollerslev, T. (1997). Answering the Skeptics: Yes, Standard Volatility Models do Provide Accurate Forecast. International Economic Review, 39(4), 885905.

Andersen, T.G. and Bollerslev, T. (1997). Intraday periodicity and volatility persistence in financial markets. Journal of Emperical Finance, 4, 115-158.

Antonakakis, N. and Filis, G. (2013). Oil Prices and Stock Market Correlation: A TimeVarying Approach. International Journal of Energy and Statistics, 1(1), 17-29.

Antonakakis, N., Chatziantoniou, I. and Filis, G. (2013). Dynamic co-movements of stock market returns, implied volatility and policy uncertainty. Economics Letters, 120 (1), 87-92. 
Apergis, N. and Miller, S.M. (2009). Do structural oil - market shocks affect stock prices? Energy Economics, 31(4), 569-575.

Arouri, M. E. H. and Rault, C. (2012). Oil Prices and Stock Markets in GCC Countries: Empirical Evidence from Panel Analysis. International Journal of Finance and Economics, 17(3), 242-253.

Arouri, M.E.H. and Nguyen, D.K. (2010). Oil prices, stock markets and portfolio investment: Evidence from sector analysis in Europe over the last decade. Energy Policy, 38, 4528- 4539.

Baba, Y., Engle, R. F., Kraft, D. F. and Kroner, K. F. (1991). Multivariate Simultaneous Generalized ARCH, Unpublished manuscript. Department of Economics, University of California: San Diego.

Barsky, R.B. and Kilian, L. (2004). Oil and the macroeconomy since the 1970s. Journal of Economic Perspectives, 18, 115-134.

Bashar, A.Z. 2006. Wild oil prices, but brave stock markets! The case of GCC stock markets. Operational Research, 6(2), 145-162.

Baum, C.F., Caglaynan, M. and Talavera O. (2010). On the sensitivity of firms' investment to cash flow and uncertainty. Oxford Economic Papers, 62, 286-306.

Baumeister, C. and Peersman, G. (2012). Time-Varying Effects of Oil Supply Shocks on the U.S. Economy. Bank of Canada Working Paper Series, 12-2.

Beine, M., Laurent, S. and Lecourt, C. (2000). Accounting for Conditional Leptokurtosis and Closing Days Effects in FIGARCH Models of Daily Exchange Rates. Forthcoming in Applied Financial Economics.

Bharn, R. and Nikolovann, B. (2010). Global Oil Prices, Oil Industry and Equity Returns: Russian Experience. Scottish Journal of Political Economy, 57(2), 169-186.

Blanchard, J.O. and Gali, J. (2007). The macroeconomic effects of oil price shocks. Why are the 2000s so different than the 1970s? National Bureau of Economic Research, Working Paper 13368.

Bloom, N. (2009). The impact of uncertainty shocks. Econometrica, 77, 623-685.

Bollerslev, T. (1986). Generalized autoregressive conditional heteroskedasticity, Journal of Econometrics, 31,307-27.

Bollerslev, T. (1987). A Conditionally Heteroskedastic Time Series Model for Speculative Prices and Rates of Return. Review of Economics and Statistics, 69, 542-547.

Boyer, M.M. and Filion, D. (2007). Common and fundamental factors in stock returns of Canadian oil and gas companies. Energy Economics, 29, 428-53.

Broadstock, D. and Filis, G. (2014). Oil price shocks and stock market returns: New evidence from the United States and China. Journal of International Financial Markets, Institutions and Money 33, 417-433.

Broadstock, D.C., Cao, H. and Zhang, D. (2012). Oil shocks and their impact on energy related stocks in China. Energy Economics, 34, 1888-1895.

Broyden, C.G. (1970). The Convergence of a Class of Double Rank Minimization Algorithms, 2, The New Algorithm. Journal of the Institute for Mathematics and Applications, 6, 222-231. 
Buyuksahin, B. and Robe, M.A. (2011). Does "paper oil" matter? Energy markets' financialization and equity-commodity co-movements. Working paper. The American University.

Buyuksahin, B., Haigh, M.S. and Robe, M.A. (2010). Commodities and equities: Ever a „market of one ee? Journal of Alternative Investments, 12, 76-95.

Caporin, M. and McAleer, M. (2008). Scalar BEKK and Indirect DCC. Journal of Forecasting, 27(6), 537-549.

Caporin, M. and McAleer, M. (2012). Do We Really Need Both BEKK and DCC? A Tale of Two Covariance Models. Journal of Economic Surveys, 26(4), 736-751.

Chang, C. L., McAleer, M. and Tansuchat, R. (2013). Conditional Correlations and Volatility Spillovers Between Crude Oil and Stock Index Returns. The North American Journal of Economics and Finance, 25, 116-138.

Chen, S.S. (2009). Do higher oil prices push the stock market into bear territory? Energy Economics, 32, 490-495.

Chen, W., Hamori, S. and Kinkyo, T. (2014). Macroeconomic impacts of oil prices and underlying financial shocks. Journal of International Financial Markets, Institutions and Money, 29, 1-12.

Cheng, S. and Li, Z. (2014). The Chinese Stock Market Volume II. Palgrave Macmillan.

Choi, K. and Hammoudeh, S. (2010). Volatility Behavior of Oil, Industrial Commodity and Stock Markets in a Regime-Switching Environment. Energy Policy, 38(8), 43884399.

Ciner, C. (2001). Energy Shocks and Financial Markets: Nonlinear Linkages. Studies in Nonlinear Dynamics \& Econometrics, 5(3), 203-212.

Ciner, C. (2013). Oil and stock returns: Frequency domain evidence. Journal of International Financial Markets, Institutions and Money 23, 1-11.

Cong, R.G., Wei, Y.M., Jiao, J.L. and Fan, Y. (2008). Relationships between Oil Price Shocks and Stock Market: An Empirical Analysis from China. Energy Policy, 36(9), 3544-3553.

Davis, J.S. and Haltiwanger, J. (2001). Sectoral job creation and destruction responses to oil price changes. Journal of Monetary Economics, 48, 645-512.

Degiannakis, S., Filis, G. and Floros, C. (2013). Oil and Stock Returns: Evidence from European Industrial Sector Indices in a Time-Varying Environment. Journal of International Financial Markets, Institutions and Money, 26, 175-191.

Degiannakis, S., Filis, G. and Kizys, R. (2014). The effects of oil price shocks on stock market volatility: Evidence from European data. The Energy Journal, 35, 35-56.

Doornik, J.A. (2007). Ox 5.0 - An Object-oriented Matrix Programming Language. Timberlake Consultant Ltd.

Driesprong, G., Jacobsen, B. and Maat, B. (2008). Striking oil: Another puzzle? Journal of Financial Economics, 89, 307-327.

EIA, (2013). China poised to become the world's largest net oil importer later this year. Washington: U.S Energy Information Administration.

EIA, (2014). Russia Overview. Washington: U.S Energy Information Administration.

EIA, (2015). Japan Overview. Washington: U.S Energy Information Administration.

EIA, (2015). Norway Overview. Washington: U.S Energy Information Administration. 
El-Sharif, I., Brown, D., Burton, B., Nixon, B. and Russell, A. (2005). Evidence on the nature and extent of the relationship between oil prices and equity values in UK. Energy Economics, 27, 819-30.

Engle, F. R. (2002). Dynamic Conditional Correlation: A Simple Class of Multivariate GARCH Models. Journal of Business and Economic Statistics, 20(3), 339-350.

Engle, R. F. and Kroner, K. F. (1995). Multivariate Simultaneous Generalized ARCH. Economic Theory, 11(1), 122-150.

Fattouh, B. (2011). An Anatomy of the Crude Oil Pricing System. The Oxford Institute for Energy Studies Working Paper No 40.

Filis, G. (2014). Time-varying co-movements between stock market returns and oil price shocks. International Journal of Energy and Statistics, 2(1), 27-42.

Filis, G. and Chatziantoniou, I. (2013). Financial and monetary policy responses to oil price shocks: evidence from oil-importing and oil-exporting countries. Review of Quantitative Finance and Accounting, 1-21.

Filis, G., Degiannakis, S. and Floros, C. (2011). Dynamic correlation between stock market and oil prices: The case of oil-importing and oil-exporting countries. International Review of Financial Analysis, 20(3), 152-164.

Filis, G., Degiannakis, S., and Kizys, R. (2014). The effects of oil price shocks on stock market volatility: Evidence from European data. Energy Journal, 35(1), 35-56.

Fletcher, R. (1970). A New Approach to Variable Metric Algorithms. Computer Journal, 13(3), 317-322.

Goldfarb, D. (1970). A Family of Variable Metric Methods Derived by Variational Means. Mathematics of Computation, 24(109), 23-26.

Hamilton, J. D. (2009a). Causes and Consequences of the Oil Shock of 2007-08. Brookings Papers on Economic Activity, 40(1), 215-261.

Hamilton, J. D. (2009b). Understanding Crude Oil Prices. Energy Journal, 30(2), 179-206.

Hamilton, J.D. (1996). This is what happened to the oil price-macroeconomy relationship. Journal of Monetary Economics, 38, 215-220.

Hamilton, J.D. and Wu, J.C. (2012). Risk Premia in Crude Oil Futures Prices. Working paper. University of California at San Diego.

Hansen, P. R. and Lunde, A. (2005). A forecast comparison of volatility models: does anything beat a GARCH $(1,1)$ ? Journal of Applied Econometrics, 20(7), 873-889.

Harlan, C. (2013). Japan's volatile Nikkei plummets 6.4 percent. The Washington Post, 13 June 2013.

Huang, D.R., Masulis, R.W. and Stoll, H. (1996). Energy shocks and financial markets. Journal of Futures Markets, 16(1), 1-27.

International Energy Agency, (2006). World Energy Outlook 2006. International Energy Agency.

International Energy Agency, (2014). Oil Market Report 11 April 2014. International Energy Agency, Paris.

Jones, C. M. and Kaul, G. (1996). Oil and the Stock Markets. The Journal of Finance, 51(2), 463-491.

Kaiser, T. (1996). One-Factor-GARCH Models for German Stocks - Estimation and Forecasting. Universiteit Tubingen, Working Paper. 
Kang, W., Ratti, R.A., and Yoon, K.H. (2015). The impact of oil price shocks on the stock market return and volatility relationship. Journal of International Financial Markets, Institutions and Money, 34, 41-54

Kat, H. and Oomen, R. (2007). What every investor should know about commodities. Part II. Journal of Investment Management, 5, 1-25.

Kilian, L. (2008). Exogenous oil supply shocks: how big are they and how much do they matter for the US economy? Review of Economics and Statistics, 90, 216-240.

Kilian, L. (2009). Not all oil price shocks are alike: Disentangling demand and supply shocks in the crude oil market. American Economic Review, 99(3), 1053-1069.

Kilian, L., and Park, C. 2009. The impact of oil price shocks on the U.S. stock market. International Economic Review, 50, 1267-1287.

Lardic, S. and Mignon, V. (2006). Oil prices and economic activity: An asymmetric cointegration approach. Energy Economics, 34, 3910-3915.

Lawrence, C.T. and A.L. Tits (2001). A Computationally Efficient Feasible Sequential Quadratic Programming Algorithm, SIAM Journal of Optimization, 11, 1092-1118.

Lescaroux, F. and Mignon, V. (2008). On the influence of oil prices on economic activity and other macroeconomic and financial variables. OPEC Energy Review, 32(4), 343380 .

Merton, R.C. (1980). On estimating the expected return on the market: An explanatory investigation. Journal of Financial Economics, 8, 323-361.

Miller, J.I. and Ratti, R.A. (2009). Crude oil and stock markets: Stability, instability, and bubbles. Energy Economics, 31, 559-568.

Mohanty, S. and Nandha, M. (2011). Oil risk exposure: The case of the US oil and gas sector. Financial Review, 46, 165-91.

Mohanty, S. K., Nandha, M., Turkistani, A. Q. and Alaitani, M. Y. (2011). Oil Price Movements and Stock Market Returns: Evidence from Gulf Cooperation Council (GCC) countries. Global Finance Journal, 22(1), 42-55.

Nandha, M. and Faff, R. (2008). Does oil move equity prices? A global view. Energy Economics, 30(3), 986-997.

National Energy Board, (2015). Total Crude Oil Exports by Destination. National Energy Board, Canada.

Nguyen, C. C. and Bhatti, M. I. (2012). Copula model dependency between oil prices and stock markets: Evidence from China and Vietnam. Journal of International Financial Markets, Institutions and Money, 22, 758-773.

Nordhaus, W. (2007). Who's afraid of a big bad oil shock? Brookings Papers on Economic Activity, 2, 219-240.

O'Neill T.J., Penm, J. and Terrell, R.D. (2008). The role of higher oil prices: A case of major developed countries, Research in Finance, 24, 287 - 299.

OPEC, (2014). The Annual Statistical Bulletin. Organization of the Petroleum Exporting Countries, Vienna.

Papapetrou, E. (2001). Oil price shocks, stock market, economic activity and employment in Greece. Energy Economics, 23(5), 511-532.

Park, J. and Ratti, R. A. (2008). Oil price shocks and the stock markets in the U.S. and 13 European countries. Energy Economics, 30(5), 2587-2608. 
Peters, J.P. (2001). Estimating and forecasting volatility of stock induces using asymmetric GARCH models and (Skewed) Student-t densities. University of Leige, Working Paper.

Ratti, R.A., Seol, Y. and Yoon, K.H. (2011). Relative energy price and investment by European firms. Energy Economics, 33, 721-731.

Ross, S. (1989). Information and volatility: the no-arbitrage Martingale approach to timing and resolution irrelevancy. Journal of Finance, 44(1), 1-17.

Sadorsky, P. (1999). Oil price shocks and stock market activity. Energy Economics, 21, $449-469$.

Sadorsky, P. (2001). Risk factors in stock returns of Canadian oil and gas companies. Energy Economics, 23, 17-28.

Sadorsky, P. (2012). Correlations and Volatility Spillovers Between Oil Prices and the Stock Prices of Clean Energy and Technology Companies. Energy Economics, 34(1), 248255.

Sadorsky, P. (2014). Modelling volatility and correlations between emerging market stock prices and the prices of copper, oil and wheat. Energy Economics, 43, 72-8.

Sadorsky, P., Basher, S.A. and Haug, A.A. (2012). Oil prices, exchange rates and emerging stock markets. Energy Economics 34, 227-240.

Shanno, D.F. (1970). Conditioning of Quasi-Newton Methods for Function Minimization. Mathematics of Computation, 24(111), 647-656.

Silvennoinen, A. and Thorp, S. (2013). Financialization, crisis, and commodity correlation dynamics. Journal of International Financial Markets, Institutions and Money, 24. 42-65.

Tang, K. and Xiong, W. (2012). Index investment and financialization of commodities. Financial Analyst Journal, 68, 54-74.

Wang, Y., Wu, C. and Yang, L. (2013). Oil Price Shocks and Stock Market Activities: Evidence from Oil-Importing and Oil-Exporting Countries. Journal of Comparative Economics, 41(4), 1220-1239.

Xekalaki, E. and Degiannakis, S. (2010). ARCH Models for Financial Applications. Wiley, New York.

Yao, S. and Luo, D. (2009). The economic psychology of stock market bubbles in China. The World Economy 32, 667-691. 


\section{TABLES}

Table 1. Descriptive statistics of the conditional volatility series. The sample runs from January 2000 until December 2014.

\begin{tabular}{|c|c|c|c|c|c|c|c|}
\hline & OIL & S\&P500 & SSE & NIKKEI225 & OSE & TSX & RTS \\
\hline Mean & 0.323 & 0.182 & 0.246 & 0.234 & 0.258 & 0.201 & 0.331 \\
\hline Median & 0.300 & 0.153 & 0.223 & 0.221 & 0.219 & 0.170 & 0.289 \\
\hline Maximum & 0.770 & 0.760 & 0.509 & 0.775 & 0.978 & 0.889 & 1.301 \\
\hline Minimum & 0.081 & 0.055 & 0.118 & 0.068 & 0.102 & 0.072 & 0.084 \\
\hline Std. Dev. & 0.116 & 0.099 & 0.085 & 0.076 & 0.128 & 0.109 & 0.157 \\
\hline Skewness & 1.142 & 2.726 & 1.269 & 2.828 & 2.782 & 3.248 & 2.852 \\
\hline Kurtosis & 5.011 & 13.682 & 3.976 & 17.510 & 13.171 & 18.126 & 15.645 \\
\hline Jarque-Bera & $69.119 * * *$ & $1072.881 * * *$ & $55.186^{* * *}$ & $1808.521 * * *$ & $1002.709 * * *$ & $2021.041 * * *$ & $1435.063 * * *$ \\
\hline$Q(15)$ & $583.091 * * *$ & $366.151 * * *$ & $631.84 * * *$ & $164.410 * * *$ & $484.682 * * *$ & $440.350 * * *$ & $211.351 * * *$ \\
\hline ADF-test & $-3.169 * *$ & $-4.519 * * *$ & $-4.811 * * *$ & $-5.869 * * *$ & $-3.866 * * *$ & $-4.493 * * *$ & $-5.459 * * *$ \\
\hline Observations & 179 & 179 & 179 & 179 & 179 & 179 & 179 \\
\hline
\end{tabular}

Note: Descriptive statistics correspond to the monthly conditional volatility of oil prices and six stock indices for the period January 2000 December 2014. OIL refers to the Brent oil price volatility. Q (15) refers to the Ljung-Box test with null hypothesis of linear dependency in residuals of data observation by measuring with a lag of 15.

For the unit root test (ADF), the Schwartz Bayesian information criterion has been implemented to indicate optimal lag. Critical values are gained from MacKinnon (1996) one-sided p-values.

$* * *$ indicates significance at $1 \%$ level

** indicates significance at 5\% level

*indicates significance at $10 \%$ level 
Table 2. Unconditional correlation between oil and stock market conditional volatilities. The sample runs from January 2000 until December 2014.

\begin{tabular}{ccccccc}
\hline & S\&P500 & SSE & NIKKEI225 & OSE & TSX & RTS \\
\hline OIL & 0.559 & 0.033 & 0.496 & 0.473 & 0.604 & 0.586 \\
\hline
\end{tabular}


Table 3. Diag-BEKK estimates. The sample runs from January 2000 until December 2014. Panel A: Oil-importing countries

\begin{tabular}{|c|c|c|c|c|c|c|c|c|c|}
\hline \multicolumn{4}{|c|}{ S\&P500 (the US) } & \multicolumn{3}{|c|}{ SSE (China) } & \multicolumn{3}{|c|}{ NIKKEI225 (Japan) } \\
\hline \multicolumn{10}{|c|}{ Mean Equation } \\
\hline Variable & Coefficient & S.E & t-stat & Coefficient & S.E & t-stat & Coefficient & S.E & t-stat \\
\hline OIL & 28.787 & 1.040 & $27.679 * * *$ & 29.478 & 0.972 & $30.327 * * *$ & 29.294 & 0.916 & $31.980 * * *$ \\
\hline STOCK & 14.209 & 1.498 & $9.480 * * *$ & 20.656 & 0.781 & $26.448 * * *$ & 21.626 & 0.682 & $31.709 * * *$ \\
\hline \multicolumn{10}{|c|}{ Variance Equation } \\
\hline$a_{1,1,0}$ & 3.381 & 0.980 & $3.449 * * *$ & 3.344 & 0.584 & $5.727 * * *$ & 3.124 & 0.675 & $4.623 * * *$ \\
\hline$a_{2,2,0}$ & 2.769 & 0.587 & $4.714^{* * *}$ & 1.696 & 0.890 & $1.904 *$ & 3.980 & 0.503 & $7.902 * * *$ \\
\hline$a_{1,2,0}$ & 0.177 & 0.573 & 0.309 & 0.555 & 0.567 & 0.977 & 0.762 & 0.632 & 1.205 \\
\hline $\boldsymbol{A}_{1}(1,1)$ & 0.983 & 0.068 & $14.455 * * *$ & 0.999 & 0.069 & $14.478 * * *$ & 0.964 & 0.076 & $12.684 * * *$ \\
\hline $\boldsymbol{A}_{1}(2,2)$ & 0.857 & 0.116 & $7.386^{* * *}$ & 0.607 & 0.124 & $4.880 * * *$ & 0.748 & 0.170 & $4.387 * * *$ \\
\hline $\boldsymbol{B}_{1}(1,1)$ & 0.183 & 0.239 & 0.765 & 0.001 & 0.039 & 0.001 & 0.264 & 0.139 & $1.895^{*}$ \\
\hline $\boldsymbol{B}_{1}(2,2)$ & 0.391 & 0.143 & $2.731 * * *$ & -0.759 & 0.108 & $-6.987 * * *$ & -0.033 & 0.094 & -0.348 \\
\hline$v$ & 6.673 & 1.631 & $4.091 * * *$ & 7.029 & 1.748 & $4.021 * * *$ & 5.444 & 0.895 & $6.078 * * *$ \\
\hline $\log \mathrm{L}$ & \multicolumn{3}{|c|}{-1146.640} & \multicolumn{3}{|c|}{-1182.392} & \multicolumn{3}{|c|}{-1149.572} \\
\hline $\mathrm{J}-\mathrm{B}$ test & \multicolumn{3}{|c|}{$737.349 * * *$} & \multicolumn{3}{|c|}{$140.020 * * *$} & \multicolumn{3}{|c|}{$690.568 * * *$} \\
\hline $\mathrm{Q}(15)$ & \multicolumn{3}{|c|}{$869.861 * * *$} & \multicolumn{3}{|c|}{$1245.973 * * *$} & \multicolumn{3}{|c|}{$711.160 * * *$} \\
\hline $\mathrm{Q}^{2}(15)$ & \multicolumn{3}{|c|}{$667.662 * * *$} & \multicolumn{3}{|c|}{$409.331 * * *$} & \multicolumn{3}{|c|}{$458.582 * * *$} \\
\hline \multicolumn{10}{|c|}{ Panel B: Oil-exporting countries } \\
\hline & \multicolumn{3}{|c|}{ OSE (Norway) } & \multicolumn{3}{|c|}{ TSX (Canada) } & \multicolumn{3}{|c|}{ RTS (Russia) } \\
\hline \multicolumn{10}{|c|}{ Mean Equation } \\
\hline Variable & Coefficient & S.E & t-stat & Coefficient & S.E & t-stat & Coefficient & S.E & t-stat \\
\hline OIL & 28.329 & 1.031 & $27.477 * * *$ & 28.395 & 2.101 & $13.51 * * *$ & 29. 241 & 0.769 & $38.024 * * *$ \\
\hline STOCK & 22.497 & 1.749 & $12.862 * * *$ & 17.437 & 1.140 & $15.29 * * *$ & 27.849 & 0.934 & $29.816^{* * *}$ \\
\hline \multicolumn{10}{|c|}{ Variance Equation } \\
\hline$a_{1,1,0}$ & 3.150 & 0.705 & $4.469 * * *$ & 3.140 & 3.434 & 0.914 & 3.690 & 0.602 & $6.122 * * *$ \\
\hline$a_{2,2,0}$ & 4.584 & 0.792 & $5.781 * * *$ & 3.365 & 1.744 & $1.929 *$ & 5.045 & 0.816 & $6.178 * * *$ \\
\hline$a_{1,2,0}$ & 0.676 & 0.710 & 0.953 & 0.748 & 0.548 & 1.363 & 2.624 & 0.990 & $2.649 * * *$ \\
\hline $\boldsymbol{A}_{1}(1,1)$ & 0.979 & 0.064 & $15.296 * * *$ & 0.993 & 0.152 & $6.513 * * *$ & 0.999 & 0.059 & $16.932 * * *$ \\
\hline $\boldsymbol{A}_{1}(2,2)$ & 0.880 & 0.108 & $8.105 * * *$ & 0.917 & 0.148 & $6.181 * * *$ & 0.820 & 0.091 & $8.964 * * *$ \\
\hline
\end{tabular}




\begin{tabular}{|c|c|c|c|c|c|c|c|c|c|}
\hline $\boldsymbol{B}_{1}(1,1)$ & 0.201 & 0.117 & $1.720 *$ & 0.109 & 2.444 & 0.044 & 0.001 & 0.192 & 0.001 \\
\hline $\boldsymbol{B}_{1}(2,2)$ & -0.039 & 0.128 & -0.303 & -0.126 & 2.063 & -0.061 & -0.334 & 0.113 & $-2.952 * * *$ \\
\hline$v$ & 6.029 & 1.336 & $4.513 * * *$ & 5.963 & 1.464 & $4.071 * * *$ & 5.371 & 0.959 & $5.596 * * *$ \\
\hline $\log \mathrm{L}$ & & -1194.971 & & & -1138.700 & & & -1241.822 & \\
\hline $\mathrm{SBC}$ & & 13.641 & & & 13.012 & & & 14.164 & \\
\hline $\mathrm{J}-\mathrm{B}$ test & & $4188.871^{* * *}$ & & & $87.145^{* * *}$ & & & $2966.412 * * *$ & \\
\hline $\mathrm{Q}(15)$ & & $1166.34 * * *$ & & & $956.314 * * *$ & & & $749.811 * * *$ & \\
\hline$Q^{2}(15)$ & & $209.622 * * *$ & & & $263.214 * * *$ & & & $516.752 * * *$ & \\
\hline
\end{tabular}

Note: The table exhibits the estimated results of the Diag-BEKK model using the monthly conditional volatilities (based on the GARCH(1,1) estimates), for the period January 2000-December 2014. OIL represents the Brent oil price volatility and STOCK represents the six individual stock market volatilities. Log L indicates log likelihood. The SBC (Schwarz Bayesian criterion) criterion represents the goodness of model fitted. We checked for normality by the J-B test (Jarque-Bera) and for autocorrelation by the Ljung-Box tests (Q) to standardized residuals and squared standardized residuals in order of 15 lags.

$* * *, * *, *$ indicates significance at $1 \%, 5 \%$ and $10 \%$ level. 
Table 4. Time-varying correlations during different economic and geopolitical events.

\begin{tabular}{llll}
\hline Period & Event & oil-importing countries & oil-exporting countries \\
\hline $2000-2001$ & Early-2000 recession & positive & positive \\
2001 & $9 / 11$ terrorist attack & positive & positive \\
2003 & US invasion in Iraq & positive & negative \\
$2004-2005$ & Atlantic hurricanes & negative & negative \\
$2006-2007$ & Economic growth of China & positive (negative for SSE) & positive (negative) \\
$2007-2009$ & The global financial crisis & positive & positive \\
$2011-2014$ & The Middle East conflicts & positive & negative (positive) \\
2014 & Collapse of the oil price & positive & positive (negative) \\
\hline
\end{tabular}




\section{FIGURES}

Figure 1. Conditional and realized volatility fluctuations for the oil and the six stock markets. The sample runs from January 2000 until December 2014.
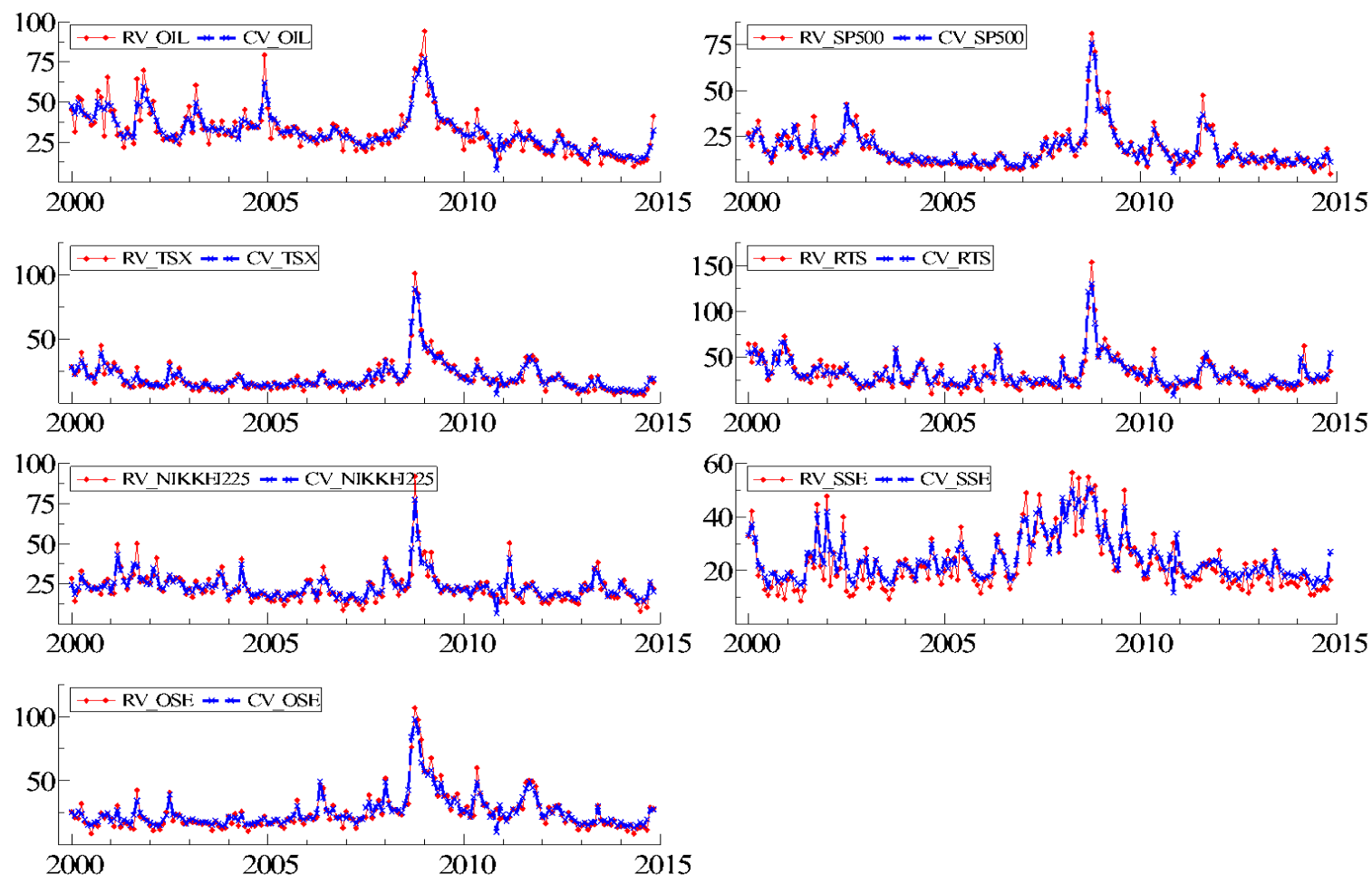
Figure 2. Time-varying correlation between oil and stock market conditional volatilities (oilimporting countries). The sample runs from January 2000 until December 2014.

\section{The US: S\&P500}

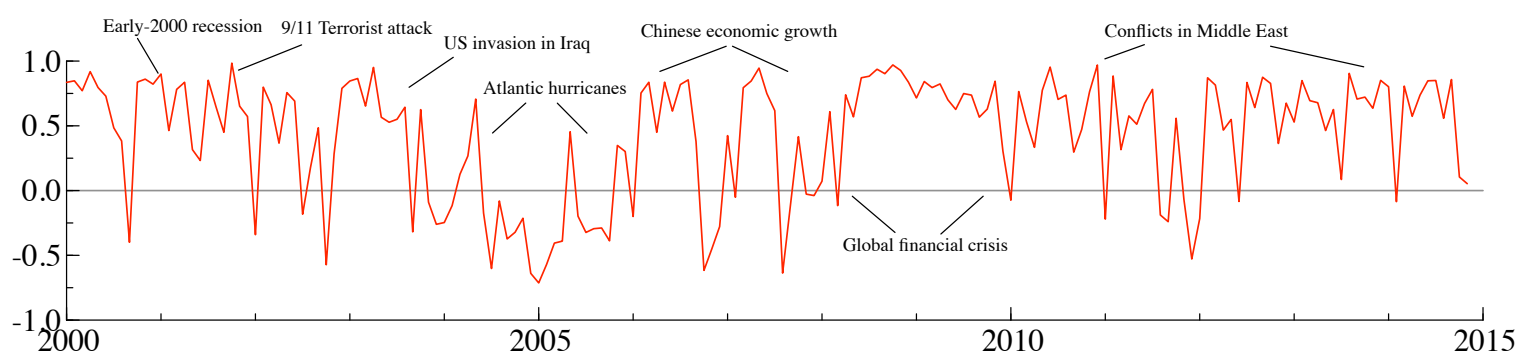

China: SSE

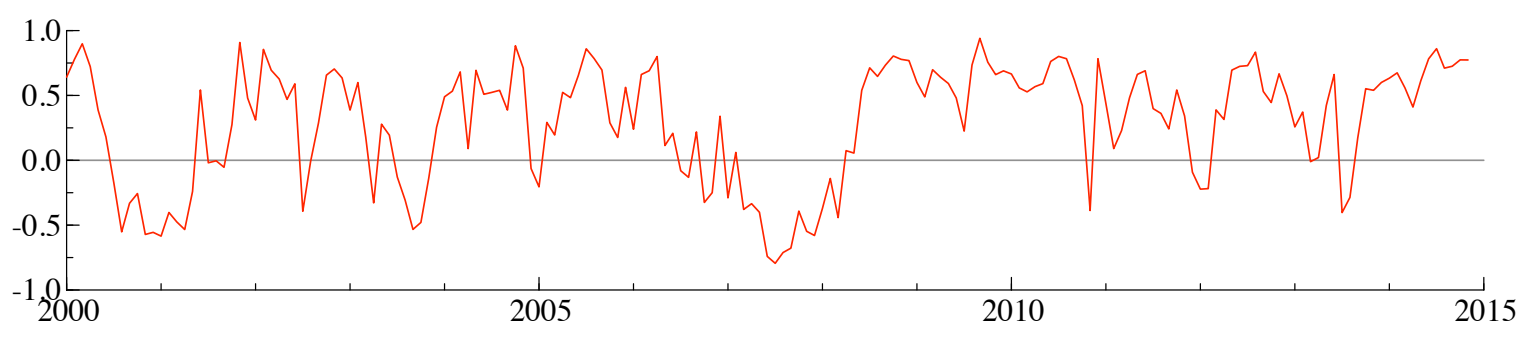

Japan: NIKKEI225

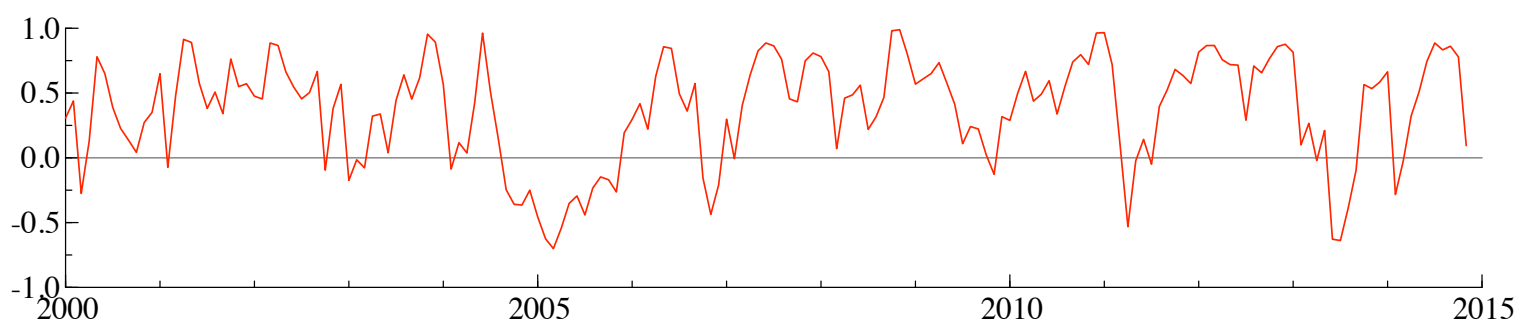


Figure 3. Time-varying correlation between oil and stock market conditional volatilities (oilexporting countries). The sample runs from January 2000 until December 2014.

Norway: OSE

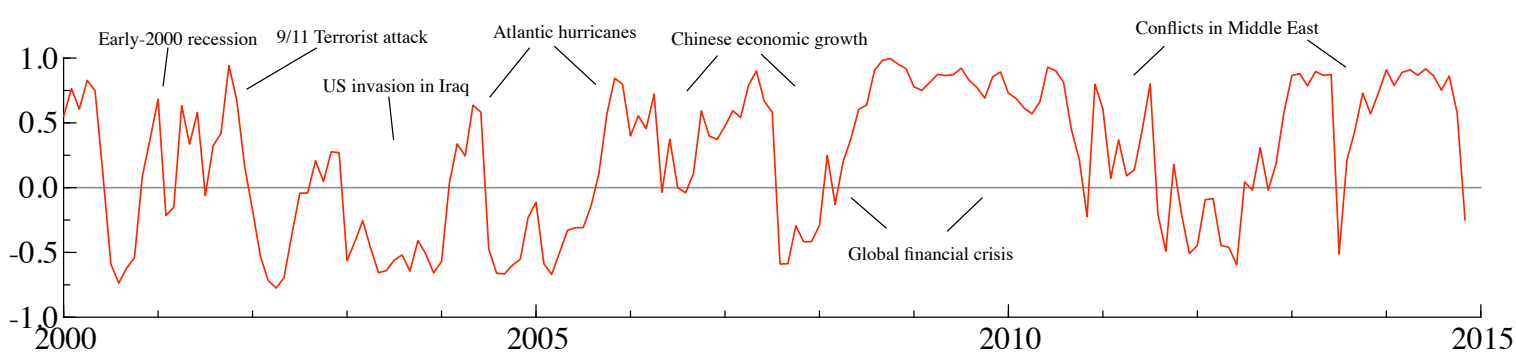

Russia: RTS

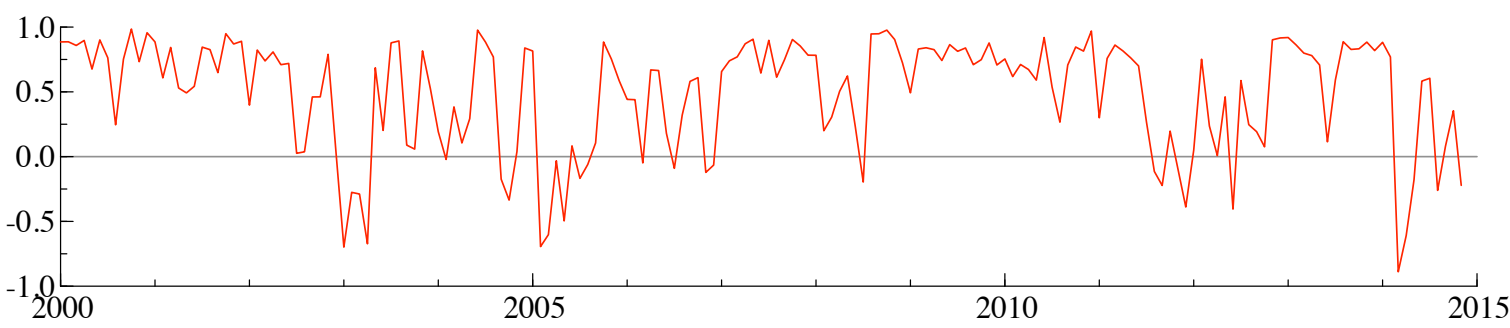

Canada: TSX

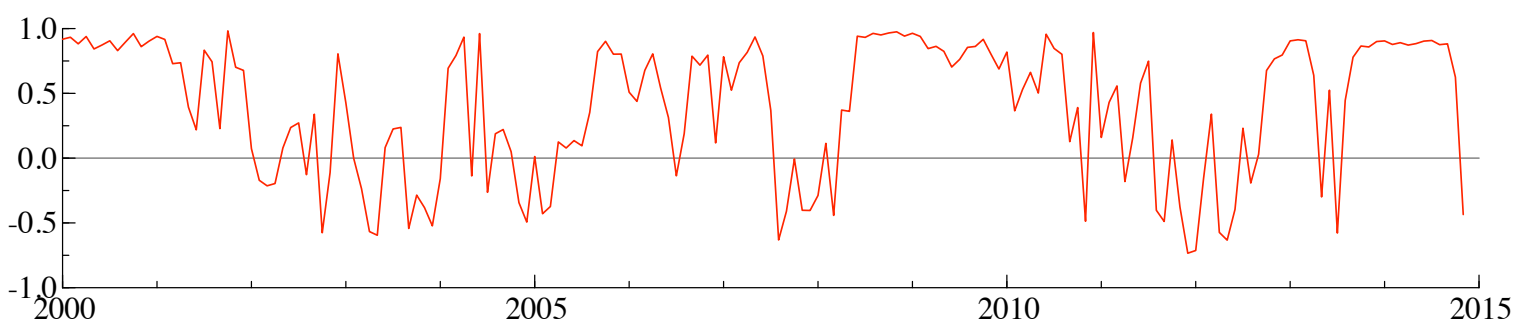




\section{Appendix: Time-varying correlations between oil and stock market realized volatilities}

Figure A1. Time-varying correlation between oil and stock market realized volatilities (oilimporting countries). The sample runs from January 2000 until December 2014.

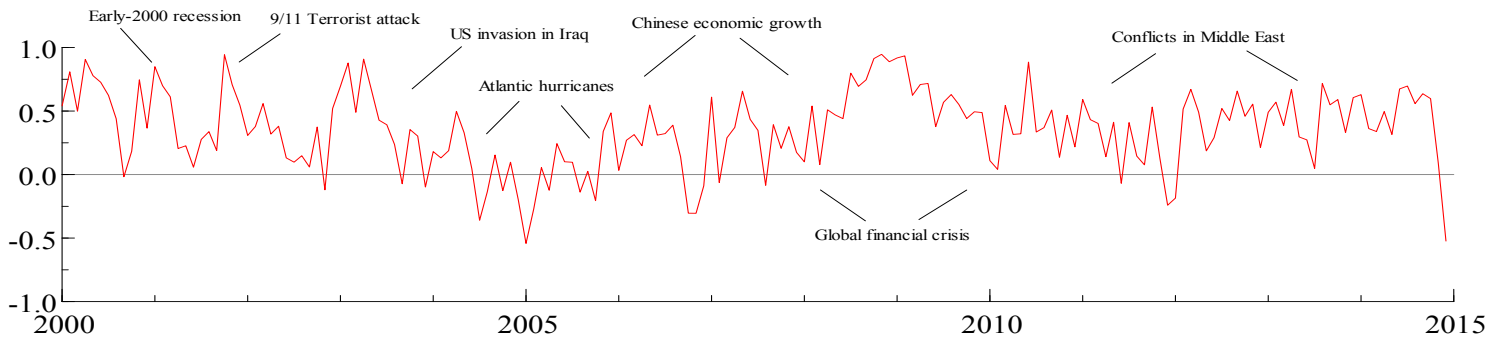

\section{China: SSE}

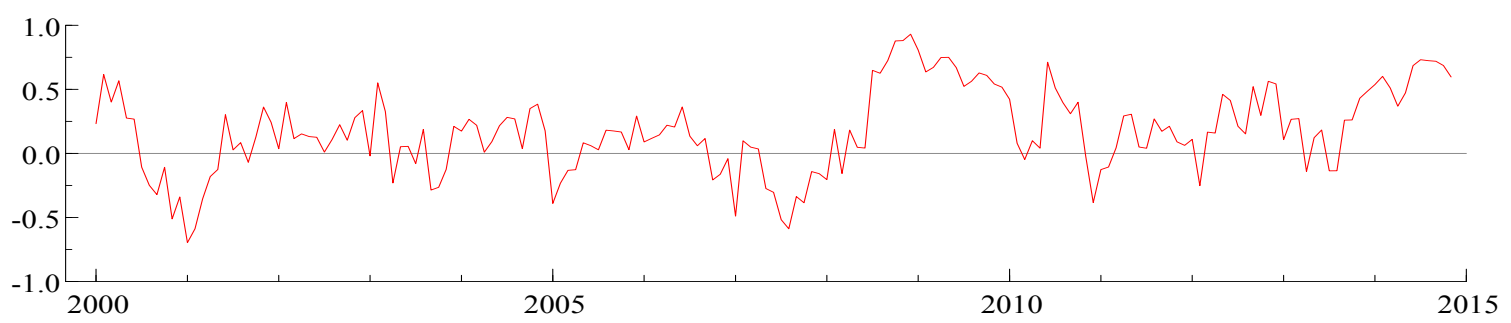

Japan: NIKKEI225

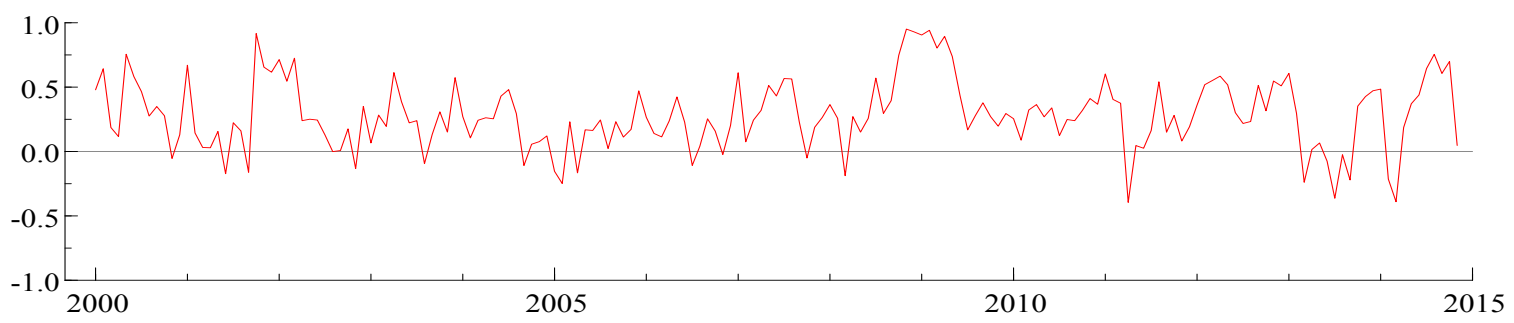


Figure A2. Time-varying correlation between oil and stock market realized volatilities (oilexporting countries). The sample runs from January 2000 until December 2014.

Norway: OSE

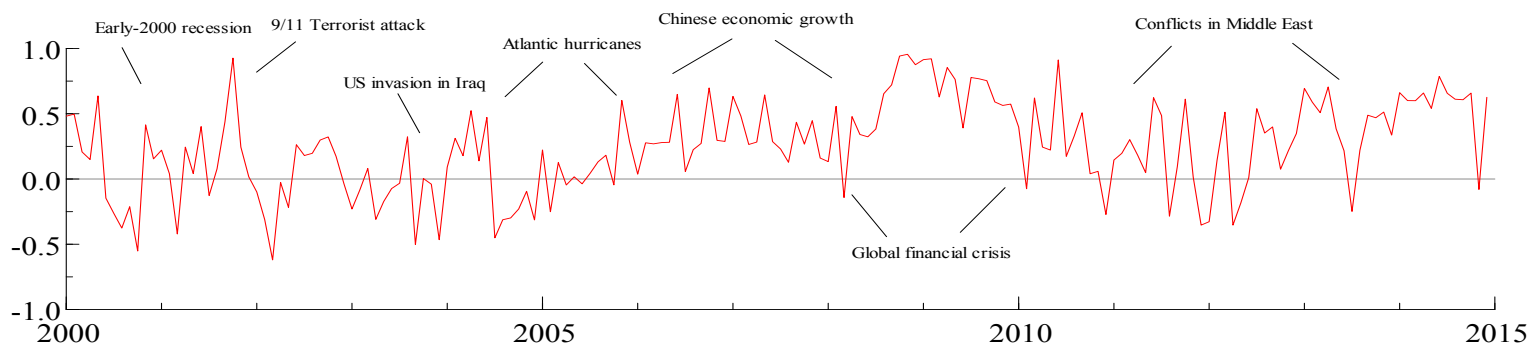

\section{Russia: RTS}

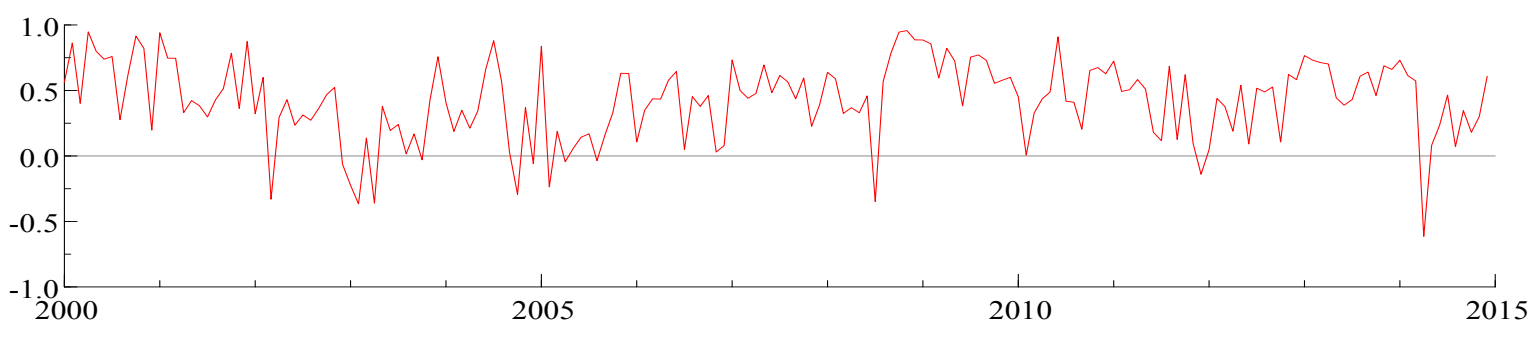

Canada: TSX

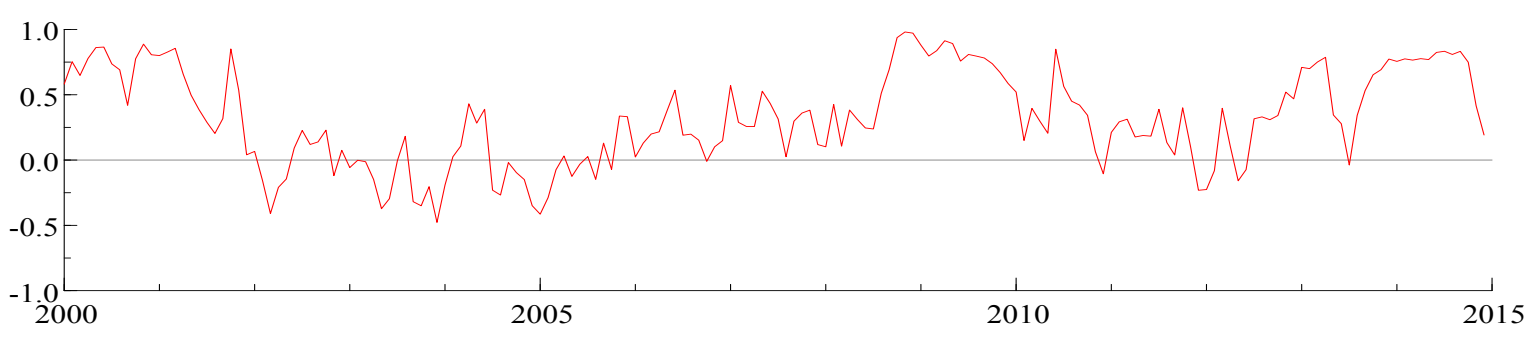

